\title{
Regional organisations in geoscience
}

This issue of Episodes covers the theme of regional organisations in geoscience and presents reviews of four examples with quite different origins and histories but which which have the common aim of promoting the exchange and application of geoscience data between nations.

Collaboration among geoscientists across international borders is nothing new and has been going on between individuals and institutions for many decades, since the first professionals realised that geological phenomena are not confined by political boundaries. Closer collaboration and cooperation at a national level was established within groups of nations sharing a common language under colonial and other political groupings. The British organisation Colonial Geological Surveys was a good example and, like others of its kind, provided close links between geological surveys which were primarily concerned with basic geological mapping and the evaluation of mineral, energy and water resources primarily for the benefit of the imperialists. Many other groupings with varying degrees of formality emerged under similar circumstances within different 'empires'.

Beginning in the nineteen sixties, with the dismemberment of the last surviving empires, new kinds of organisations in geoscience began to emerge, with United Nations support. IUGS itself arose at this time with the support of UNESCO and was aimed primarily at fostering cooperation in scientific research especially between nations politically separated by the Cold War. An account of the history and present organisation of IUGS may be found in Episodes vol. 17, no. 4.

Different again, but also initially founded under the auspices of the United Nations (in this case UNDP) is CCOP, an organisation of East and Southeast Asian countries. This is a grouping by formal agreement between regional governments, albeit stimulated by geoscientists, rather than between geoscience institutions or individuals. Dr Kim Sahng Yup the current Director of the CCOP Technical Secretariat explains how the organisation has developed and its present status as an influential body with a voice in developmental matters.

In Africa, the Geological Society of Africa, founded in 1973, has similar objectives to those of CCOP but came about from the initiative of individual scientists, mainly from acad- emia, rather than at the instigation of governments or government geological surveys. GSA has had little support or recognition from either national governments or regional economic or political organisations. The current President, Professor Sospeter Muhongo, in his article on the GSA, does not flinch from voicing the concern of African geoscientists at this disregard, on the part of governments and organisations, of the important role that organised geoscience can play in alleviating some of the ills of the African continent.

The Association of Geoscientists for International Development, AGID, described herein by Dr Tony Reedman, Secretary General, is also non-governmental and also arose in the early 1970 s by the initiative of individual geoscientists concerned about the dwindling local geoscientific manpower resources in developing countries following independence. Emphasis was on the encouragement of dialogue between individuals in developing countries with their counterparts in the so-called developed countries. The outcome today is a unique network of geoscientists dedicated to promoting the role of geoscience in economic and social development.

The newest regional geoscientific organisation is EuroGeoSurveys, which came into existence in 1995 as a result of an initiative by the Directors of the 15 national geological surveys of the European Union. Described in an article by $\mathrm{Dr}$ Richard Annells, the current Secretary General, EuroGeoSurveys plans to make use of the immense information resource amassed by its member institutions over an average existence of 119 years. A prime and key objective is to bring to the attention of EU decision makers, the critical importance of geoscience to issues involving natural resources, the environment and natural hazards.

A common theme implicit in all four articles is an emphasis on the the role that trained geoscientists must play in sustainability issues and in influencing decision makers to adopt policies that are not simply based on economics and considerations of market-forces in isolation of the natural environment and the quality of life of masses of urban dwellers forced to live in ever-growing conurbations in unstable coastal zones.

\section{Rodney Walshaw}

